\title{
EVALUASI SIFAT KIMIA TANAH DAN HASIL KEDELAI PADA SISTEM AGROFORESTRI BERBASIS POHON JATI
}

\author{
Deni Prasetiyo ${ }^{1)}$, Djoko Purnomo ${ }^{2)}$ dan Supriyadi ${ }^{2)}$ \\ ${ }^{1)}$ Mahasiswa Program Studi Agroteknologi Fakultas Pertanian UNS \\ ${ }^{2)}$ Program Studi Agroteknologi Fakultas Pertanian UNS \\ Email: djpuruns@gmail.com
}

\begin{abstract}
Soybean is one of the most important food commodities in Indonesia and also it has high value. The needs continue to increase each year, but not offset by increased production become an issue that must be addressed. One attempt to increase soybean production is through the cultivation in agroforestry systems through improving the quality of soil fertility. This research aims to study the effect of various doses of litter teak and NPK fertilizer on chemical soil fertility and the potential of soybeans yield in agroforestry systems based teak crops. Experiments using a Randomized Complete Block Design (RCBD) with two factors, namely litter teak doses (0 ton ha-, 2.500 ton ha ${ }^{-1}, 5.000$ ton $\mathrm{ha}^{-1}, 7.500$ ton $\mathrm{ha}^{-1}$ ) and doses of NPK fertilizer (60-60-60 and 60-120-60) on Grobogan soybean varieties. The variables measured were $\mathrm{pH}$, organic matter content, $N$-total soil, cation exchange capacity (CEC), plant tissue of $N$, P-total soil, and component production. Data analysis using analysis of variance F-test based on the level of $5 \%$ and significantly different variables followed by Tukey's method level of 5\%. The results showed that combination treatment with various doses of teak litter NPK fertilizers can increase total nitrogen content of the soil with the highest yield of $1.69 \%$ on S1D2 treatment, but to organic matter, CEC, $p H$, and total soil P not significant effect. Component of soybean varieties of the highest Grobogan of 0.83 tons ha-1 in the treatment S1D1. The result was still below the average of the national soybean production.
\end{abstract}

Keywords: agroforestry, litter teak, soil chemical properties, soybean

\section{PENDAHULUAN}

Kedelai (Glycine max L.) merupakan komoditas yang penting dan bernilai ekonomi tinggi. Selain dimanfaatkan sebagai bahan pangan, kedelai juga dapat digunakan sebagai bahan baku industri dan pakan ternak. Pengembangan kedelai juga memberi kontribusi terhadap perekonomian nasional (Produk Domestik Bruto sub sektor tanaman pangan) meskipun nilainya masih relatif kecil dibandingkan komoditi tanaman pangan lainnya. Badan Pusat Statistik (2013) menyatakan bahwa produksi kedelai tahun 2013 mengalami penurunan sebesar 7,47\% dibanding tahun 2012. Hal tersebut menyebabkan kebutuhan kedelai tidak tercukupi sehingga harus dilakukan impor.

Banyak kedelai telah dibudidayakan di hutan lindung yang merupakan kawasan hutan yang dianggap sebagai daerah untuk menyimpan fungsi ekologis, meskipun hutan bukan merupakan wilayah yang tepat sebagai daerah budidaya kedelai, karena akan mengalami kehampaan polong yang tinggi. Kehampaan polong tersebut diduga berasal dari kesuburan tanah, bukan kekurangan cahaya atau air karena kedelai merupakan tanaman C3 yang relatif toleran terhadap penyinaran yang rendah sedangkan kebutuhan air sudah tercukupi dari air hujan. Pengisian biji kedelai memerlukan ketersediaan unsur hara tinggi, terutama $\mathrm{N}$ dan $\mathrm{P}$. Tingginya keperluan unsur hara selain karena kandungan protein biji tinggi juga karena terjadi immobilisasi unsur $\mathrm{N}$ untuk dekomposisi bahan organik.Secara umum, faktor pembatas kinerja sistem agroforestri adalah kesuburan tanah, air, dan cahaya berhubungan dengan interaksi tanaman dan pohon (Purnomo dan Sitompul 2005).

Kombinasi penambahan beberapa dosis bahan organik dengan pupuk anorganik diharapkan mampu mengatasi kendala dalam budidaya kedelai sistem agroforestri tersebut. Maka perlu dilakukan pengkajian melalui sebuah penelitian mengenai pengaruh penambahan berbagai dosis bahan organik dengan pupuk anorganik terhadap kesuburan kimia tanah dan hasil kedelai sistem agroforestri. 


\section{METODE PENELITIAN}

Penelitian ini dilaksanakan pada bulan November 2013 sampai bulan April 2014 di Desa Tambak Merang, Girimarto, Wonogiri. Analisis laboratorium dilaksanakan di Laboratorium Kimia dan Kesuburan Tanah Fakultas Pertanian Universitas Sebelas Maret Surakarta. Bahan yang digunakan dalam penelitian ini meliputi benih kedelai varietas Grobogan, pupuk urea, pupuk SP-36, pupuk $\mathrm{KCl}$, seresah jati, dan khemikalia untuk analisis laboratorium. Alat yang digunakan untuk penelitian meliputi timbangan analitik, oven, grinder, kamera, alat tulis, dan alat-alat untuk analisis laboratorium.

Penelitian disusun dengan Rancangan Acak Kelompok Lengkap (RAKL) dengan dua faktor. Faktor pertama adalah pemberian berbagai dosis seresah jati terdiri dari 5 taraf yaitu 0 ton $\mathrm{ha}^{-1}, 2.500$ ton $\mathrm{ha}^{-1}, 5.000$ ton ha', 7.500 ton $\mathrm{ha}^{-1}$, dan 10.000 ton ha $\mathrm{ha}^{-1}$. Faktor kedua adalah pemupukan NPK yang terdiri dari 2 taraf yaitu NPK 60-60-60 dan NPK 60120-60. Berdasarkan 2 faktor tersebut diperoleh 10 kombinasi perlakuan. Setiap perlakuan diulang 3 kali sehingga diperoleh 30 petak percobaan.
Pelaksanaan penelitian melalui tahaptahap yaitu survei lokasi, pengolahan lahan, penanaman, pemeliharaan, pengamatan tanaman, dan pengamatan. Variabel tanah yang diamati meliputi $\mathrm{pH}$ tanah, $\mathrm{N}$ total, KTK, bahan organik, P total, dan Serapan N. Untuk variabel tanaman yang diamati adalah biomassa tanaman dan hasil kedelai. Data yang diperoleh dianalisis menggunakan analisis ragam berdasarkan uji $\mathrm{F}$ taraf $5 \%$. Apabila terdapat pengaruh nyata dilanjutkan dengan uji Tukey taraf 5\%.

\section{HASIL DAN PEMBAHASAN}

\section{Kesuburan Kimia Lahan Agroforestri}

Hasil analisis data statistik berdasarkan uji $\mathrm{F}$ dan Tukey taraf 5\% pada variabel yang diamati menunjukkan perlakuan kombinasi berbagai dosis seresah jati dengan pupuk NPK memberikan pengaruh nyata terhadap kandungan $\mathrm{N}$ total tanah, seperti terlihat pada tabel 1. Akan tetapi, terhadap variabel Bahan Organik, Kapasitas Tukar kation (KTK), pH, Serapan N, P total, Biomassa Tanaman, dan Berat Biji 1 Tanaman, seperti terlihat pada tabel 2.

Tabel 1. Hasil uji tukey taraf 5\% terhadap N total tanah

\begin{tabular}{cc}
\hline Perlakuan & $\begin{array}{c}\text { N total } \\
(\%)\end{array}$ \\
\hline S1D1 & $0,91 \mathrm{c}$ \\
S1D2 & $1,69 \mathrm{a}$ \\
S2D1 & $1,04 \mathrm{bc}$ \\
S2D2 & $1,63 \mathrm{ab}$ \\
S3D1 & $1,08 \mathrm{abc}$ \\
S3D2 & $1,28 \mathrm{abc}$ \\
S4D1 & $1,42 \mathrm{abc}$ \\
S4D2 & $1,05 \mathrm{abc}$ \\
S5D1 & $1,12 \mathrm{abc}$ \\
S5D2 & $1,47 \mathrm{abc}$ \\
\hline
\end{tabular}

Keterangan : Huruf yang sama menunjukkan berbeda tidak nyata pada uji tukey $5 \%$.

Berdasarkan hasil statistik terhadap $\mathrm{N}$ total tanah, perlakuan kombinasi berbagai dosis seresah jati dengan pupun NPK memberikan pengaruh sangat nyata terhadap $\mathrm{N}$ total tanah $(\mathrm{P}=0,003)$. Dari uji Tukey $5 \%$ dapat diketahui bahwa perlakuan S1D2 berbeda nyata dengan S1D1 dan S2D1, sedangkan S2D2 hanya berbeda nyata dengan S1D1. N total tanah tertinggi tercapai pada perlakuan S1D2, yaitu kombinasi seresah jati 0 ton ha ${ }^{-1}$ dengan pupuk NPK 60-120-60 dengan persentase peningkatan sebesar $85,7 \%$ dibandingkan S1D1 dan meningkat 62,5\% dibandingkan S2D1.

Meningkatnya $\mathrm{N}$ total lebih disebabkan karena penggunaan pupuk NPK dibandingkan dengan penambahan seresah jati. Meskipun seresah jati mengandung berbagai unsur hara yang dibutuhkan tanaman namun jumlahnya belum mampu memenuhi kebutuhan tanaman. Selain itu, seresah jati merupakan seresah yang berkualitas rendah yang justru menyebabkan mikroorganisme tanah menjauh sehingga sulit terdekomposisi. Menurut Buckman dan 
Brady (1982), pupuk yang telah mengalami hidrolisa dalam tanah akan menghasilkan amonium karbonat yang akan mengalami proses nitrifikasi cepat dalam menyajikan ion $\mathrm{NH}_{4}{ }^{+}$ataupun ion $\mathrm{NO}_{3}{ }^{-}$sehingga kandungan $\mathrm{N}$ total tanah dapat meningkat.
Pengamatan terhadap Bahan Organik, Kapasitas Tukar kation (KTK), pH, Serapan N, P total, Biomassa Tanaman, dan Berat Biji 1 Tanaman, perlakuan kombinasi berbagai dosis seresah jati dengan pupuk NPK tidak memberikan pengaruh yang nyata seperti ditunjukkan pada tabel 2.

Tabel 2. Hasil uji tukey taraf 5\% terhadap bahan organik, KTK, pH, dan P total

\begin{tabular}{ccccc}
\hline Perlakuan & $\begin{array}{c}\text { BO } \\
(\%)\end{array}$ & $\begin{array}{c}\text { KTK } \\
(\mathrm{me} \%)\end{array}$ & $\mathrm{pH}$ & $\begin{array}{c}\text { P Total } \\
(\%)\end{array}$ \\
\hline S1D1 & 2,22 & 17,80 & 4,87 & 6,48 \\
S1D2 & 2,20 & 21,25 & 5,17 & 6,02 \\
S2D1 & 2,30 & 19,76 & 5,17 & 6,81 \\
S2D2 & 2,21 & 21,60 & 5,00 & 5,97 \\
S3D1 & 2,26 & 21,07 & 4,93 & 6,19 \\
S3D2 & 2,15 & 19,53 & 5,37 & 6,20 \\
S4D1 & 1,92 & 19,33 & 5,43 & 6,24 \\
S4D2 & 2,13 & 18,27 & 5,57 & 6,05 \\
S5D1 & 2,14 & 20,80 & 5,53 & 6,54 \\
S5D2 & 2,10 & 18,13 & 4,73 & 6,60 \\
\hline
\end{tabular}

Berdasarkan analisis ragam terhadap kandungan bahan organik tanah, bahwa perlakuan kombinasi berbagai dosis seresah jati dengan pupuk NPK menunjukkan pengaruh yang tidak nyata $(\mathrm{P}=0,249)$. Alfisols diketahui memiliki kandungan bahan organik yang rendah. Rendahnya bahan organik ini disebabkan karena proses dekomposisi berjalan lambat yang diduga dipengaruhi oleh kualitas seresah yang rendah, yaitu memiliki kandungan lignin 14,54\% dengan $\mathrm{C} / \mathrm{N}$ rasio sebesar 32 (Purwanto et al. 2014). Menurut Palm et al. (1991) seresah dikatakan memiliki kualitas tinggi apabila kandungan $\mathrm{C} / \mathrm{N}$ rasio kurang dari 25, dan kandungan lignin $<15 \%$.

Berdasarkan analisis ragam menunjukkan bahwa perlakuan kombinasi berbagai dosis seresah jati dengan pupuk NPK tidak memberikan pengaruh terhadap Kapasitas Tukar Kation (KTK) tanah. KTK tanah erat kaitannya dengan pupuk organik, dalam hal ini adalah seresah jati. Seresah jati yang telah terdekomposisi menjadi pupuk organik bersifat sebagai koloid yang mampu menjerap kation. Peran bahan organik pada sifat kimia tanah yaitu meningkatkan kapasitas penjerapan dan pertukaran kation dalam tanah (Karieen 2008). Dikarenakan kandungan bahan organik hasil dekomposisi seresah jati dalam tanah sedikit, hal tersebut berpangaruh terhadap penjerapan kation dalam tanah yang sedikit pula.
Hasil analisis ragam menunjukkan bahwa kombinasi berbagai dosis seresah jati dengan pupuk NPK tidak berpengaruh nyata terhadap $\mathrm{pH} \mathrm{H}_{2} \mathrm{O}$ tanah. Hal tersebut diduga berkaitan dengan penggunaan pupuk organik berupa seresah jati, yang diketahui memiliki $\mathrm{C} / \mathrm{N}$ rasio yang rendah. Proses dekomposisi bahan organik dengan $\mathrm{C} / \mathrm{N}$ rasio rendah akan berjalan lambat dan menghasilkan asam-asam organik yang selanjutnya melepaskan ion-ion $\mathrm{H}^{+}$dan $\mathrm{OH}^{-}$ke dalam larutan tanah sehingga akan mempengaruhi perubahan $\mathrm{pH}$ tanah (Minardi 2009).

Bersama unsur nitrogen, phospor dibutuhkan kedelai dalam pengisian biji. Berdasarkan hasil analisis ragam, menunjukkan bahwa perlakuan kombinasi berbagai dosis seresah jati dengan pupuk NPK tidak memberikan pengaruh nyata terhadap $\mathrm{P}$ total tanah. Hal tersebut diduga berkaitan dengan $\mathrm{pH}$ tanah. Menurut Djajadi et al. (2002), umumnya P lebih banyak tersedia pada $\mathrm{pH}$ mendekati netral. Diketahui bahwa $\mathrm{pH}$ tempat penelitian berada pada $\mathrm{pH}$ rendah sampai sedang sehingga mengakibatkan unsur $\mathrm{P}$ berada dalam bentuk senyawa kompleks dengan $\mathrm{Al}$ dan Fe yang kurang tersedia bagi tanaman. 


\section{Hasil Tanaman Kedelai dilahan Agroforestri}

Tabel 3. Hasil uji tukey taraf 5\% terhadap biomassa tanaman dan berat biji

\begin{tabular}{cccccc}
\hline Perlakuan & $\begin{array}{c}\text { Biomassa } \\
15 \mathrm{HST} \\
(\mathrm{g})\end{array}$ & $\begin{array}{c}\text { Biomassa } \\
\text { 30HST } \\
(\mathrm{g})\end{array}$ & $\begin{array}{c}\text { Biomassa } \\
45 \mathrm{HST} \\
(\mathrm{g})\end{array}$ & $\begin{array}{c}\text { Biomassa } \\
\text { Panen } \\
(\mathrm{g})\end{array}$ & $\begin{array}{c}\text { Berat Biji } \\
\text { (ton/ha) }\end{array}$ \\
\hline S1D1 & 2,22 & 17,80 & 4,87 & 6,48 & 0,83 \\
S1D2 & 2,20 & 21,25 & 5,17 & 6,02 & 0,67 \\
S2D1 & 2,30 & 19,76 & 5,17 & 6,81 & 0,47 \\
S2D2 & 2,21 & 21,60 & 5,00 & 5,97 & 0,67 \\
S3D1 & 2,26 & 21,07 & 4,93 & 6,19 & 0,71 \\
S3D2 & 2,15 & 19,53 & 5,37 & 6,20 & 0,47 \\
S4D1 & 1,92 & 19,33 & 5,43 & 6,24 & 0,67 \\
S4D2 & 2,13 & 18,27 & 5,57 & 6,05 & 0,69 \\
S5D1 & 2,14 & 20,80 & 5,53 & 6,54 & 0,32 \\
S5D2 & 2,10 & 18,13 & 4,73 & 6,60 & 0,68 \\
\hline
\end{tabular}

Dari pengamatan dan berdasarkan hasil analisis data terhadap biomassa tanaman, bahwa perlakuan kombinasi seresah jati dengan pupuk NPK menunjukkan tidak berpengaruh nyata pada setiap tahap pertumbuhan mulai dari saat tanaman berumur 15 HST, 30 HST, 45 HST, dan saat panen. Hasil yang tidak berpengaruh ini disebabkan karena perlakuan yang dilakukan belum mampu mencukupi kebutuhan hara-hara penting seperti $\mathrm{N}$, P, dan $\mathrm{K}$. Penambahan seresah jati dan pupuk NPK belum mampu menyediakan unsur hara bagi kebutuhan tanaman. Selain itu, adanya pohon jati diantara tanaman kedelai juga mengurangi intenstas cahaya matahari sehingga laju fotosintesis juga akan terhambat.

Hasil terhadap biomassa tanaman juga berpengaruh terhadap berat biji kedelai. Berdasarkan hasil analisis data, bahwa perlakuan kombinasi seresah jati dengan pupuk NPK menunjukkan tidak berpengaruh nyata terhadap berat biji kedelai per hektar. Banyak faktor yang diduga mempengaruhi hal tersebut selain faktor kesuburan tanah yang tergolong rendah, kualitas seresah jati yang rendah juga berpengaruh. Selain itu, sedikitnya radiasi matahari yang sampai pada tanaman karena terhalang pohon jati juga menghambat proses fotosintesis sehingga biji kedelai yang dihasilkan kurang optimal. Berat kedelai per hektar pada penelitian ini masih berada dibawah hasl rata-rata produksi nasional yaitu sebesar 1 ton ha ${ }^{-1}$. Hasil tersebut juga masih jauh berada dibawah rata-rata produksi kedelai varietas Grobogan pada kondisi yang sesuai kebutuhan kedelai yaitu sebesar 2,77 ton $\mathrm{ha}^{-1}$ (BPTPI 2010).

\section{KESIMPULAN DAN SARAN}

Penambahan kombinasi berbagai dosis seresah jati dengan pupuk NPK dapat meningkatkan kandungan $\mathrm{N}$ total tanah, namun belum dapat meningkatkan komponen hasil kedelai varietas Grobogan dalam sistem budidaya agroforestri berbasis jati. Perlu dilakukan penelitian tentang seresah jenis lain yang diberikan agar diketahui jenis seresah yang terbaik.

\section{DAFTAR PUSTAKA}

BPS 2013. Llaporan bulanan data sosial ekonomi. Badan Pusat Statistik. Jakarta.

BPTPI 2010. Kedelai varietas lokal Grobogan. http://203.176.181.70/bppi/lengkap/bpp1 0034.pdf. Diakses tanggal 16 November 2014.

Buckman, H.O. \& N. C. Brady. 1982. Ilmu Tanah (Terjemahan Soegiman). Jakarta : Penerbit Bhatara Karya Aksara.

Djajadi, M. Sholeh, dan N. Sudibyo. 2002. Pengaruh pupuk organik dan anorganik, ZA dan SP 36 terhadap hasil dan mutu tembakau Temanggung pada tanah andisols. Jurnal Littri. Vol.8. No.1.

Karieen, 2008. Bahan organik. http://karieeen.wordpress.com. Diunduh tanggal $\quad 10 \quad$ April 2015 pukul 10.00 WIB.

Minardi, Slamet, Joko Winarno, dan Abror Hanif Nur Abdillah. 2009. Efek perimbangan pupuk organik dan pupuk anorganik terhadap sifat kimia tanah 
andisol Tawangmangu dan hasil tanaman wortel (Daucus carota L.). Jurnal Sains Tanah Jurnal Ilmu Tanah dan Agroklimatologi. Vol VI, No. 2. Hal : 114.

Palm, C.A., Sanches, P.A. 1991. Nitrogen release from some tropical legumes as affected by lignin and polyphenol contents. Soil Biol. Biochem. 23: 83- 88.

Purnomo, D. dan S.M. Sitompul 2005. Peningkatan kinerja tanaman jagung dan kedelai pada sistem agroforestri jati dengan pemupukan N. Agrosains. Vol. 6 (2): 106-112.

Purwanto, Sri Hartati, dan Siti Istiqomah. 2014. Pengaruh kualitas dan dosis seresah terhadap potensial nitrifikasi tanah dan hasil jagung manis. Sains Tanah-Jurnal Ilmu Tanah dan Agroklimatologi. Volume XI. No 1. Hal : 13-14. 